\title{
Robert Garnier, Théâtre complet. Tome II: Hippolyte
}

\section{Michele Mastroianni}

\section{(2) OpenEdition}

\section{Journals}

\section{Edizione digitale}

URL: http://journals.openedition.org/studifrancesi/6249

DOI: $10.4000 /$ studifrancesi.6249

ISSN: 2421-5856

\section{Editore}

Rosenberg \& Sellier

\section{Edizione cartacea}

Data di pubblicazione: 1 novembre 2010

Paginazione: $542-543$

ISSN: 0039-2944

\section{Notizia bibliografica digitale}

Michele Mastroianni, «Robert Garnier, Théâtre complet. Tome II: Hippolyte», Studi Francesi [Online], 162

(LIV | III) | 2010, online dal 30 novembre 2015, consultato il 08 janvier 2021. URL: http://

journals.openedition.org/studifrancesi/6249; DOI: https://doi.org/10.4000/studifrancesi.6249

Questo documento è stato generato automaticamente il 7 janvier 2021.

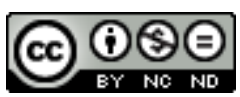

Studi Francesi è distribuita con Licenza Creative Commons Attribuzione - Non commerciale - Non opere derivate 4.0 Internazionale. 


\section{Robert Garnier, Théâtre complet. Tome II: Hippolyte}

Michele Mastroianni 


\section{NOTIZIA}

ROBERT GARNIER, Théâtre complet. Tome II: Hippolyte, édition de Jean-Dominique BEAUDIN, Paris, Éditions Classiques Garnier, 2009 («textes de la Renaissance», 159), pp. 304.

1 Nella pubblicazione del teatro completo di Robert Garnier, di cui è responsabile JeanDominique Beaudin (testi già pubblicati: Antigone, 1997; La Troade, 1999; Porcie, 1999; Cornelie, 2002; Les Juifves, 2004²), esce ora a cura del direttore dell'impresa l'edizione critica dell'Hippolyte. Pubblicata nel 1573, è la prima tragedia francese consacrata all'amore incestuoso di Fedra. Secondo il criterio già seguito nell'editare le altre pièces di Garnier, il testo scelto come base è l'ultimo rivisto dall'autore, quello del 1585. Una ricca e puntuale annotazione (pp. 175-265) non solo ripercorre i contatti con la Phaedra di Seneca, in primo luogo, e poi con l'Ippolito euripideo, ma ricostruisce la complessa rete di fonti e di riferimenti letterari, classici e cinquecenteschi. L'introduzione (pp. 11-49) è un vero saggio interpretativo della tragedia. Dato per scontato, come attesta anche, oltre alle note, un tableau comparatif, il calco senecano, viene qui evidenziata l'originalità di impostazione da parte di Garnier, originalità che appare anzitutto nei glissements de sens in senso cristiano, secondo un'operazione che governa il rifacimento cinquecentesco dei tragici classici. In particolare, in un paragrafo consacrato al Tragique et sens religieux du drame (pp. 33-42), J.-D. Beaudin sottolinea la rilettura dei due testi quello euripideo e quello senecano - secondo una linea cristiana che contrappone a un Hippolyte justifié una Phèdre reprouvée. Infine, vengono messe in luce le preoccupazioni politiche, per nulla assenti da questa tragedia di amore e di passione, e la presenza in questa pièce, come in altre di Garnier, di una riflessione sulle «questions brûlantes de l'autorité royale et de la responsabilité du monarque à l'égard de sa famille et de sa cité». Ricca la bibliografia e accurato il glossario. 